DOI: $10.1515 /$ pof-2016-0010

VOLUME 8, ISSUE 2, 2016

ISSN: 2036-5438

\title{
Mid-term review of the Multiannual Financial Framework 2014-2020 - A round-up of key issues at stake \\ by
}

Magdalena Sapała*

Perspectives on Federalism, Vol. 8, issue 2, 2016 


\begin{abstract}
By the end of 2016 the European Commission is expected to present its mid-term review of the Multiannual Financial Framework (MFF) 2014-2020. The results of the review may open the way for a revision of the MFF Regulation. The scope of the review, as laid down in the legislation, as well as the difficult implementation of the MFF in its first years, give grounds to expect changes in the MFF Regulation. However, experience of past reviews and the requirement of a unanimous vote in the Council on the revision of the MFF raise concerns about the final result of the exercise.

This paper explains how the idea of the mid-term review of the MFF has evolved, why it has become so important, and what issues are at stake at the outset of the debate. It shows that in order to ensure a smoother implementation of the MFF in the future years some radical changes are necessary, including an increase of the ceilings and flexibility. Besides, the problems with the implementation of the current MFF give arguments for a thorough reform with a view of the post-2020 MFF.
\end{abstract}

Key-words

EU budget, Multiannual Financial Framework, review, revision 


\section{Introduction}

Even a cursory review of the literature and studies on the financing of European integration leaves no doubt that the EU's budget needs reform. Experts criticise the revenue and expenditure mechanisms as well as the management rules of the budget. Back in 2003, the Sapir report described the EU budget as 'a historical relic' and called for a major overhaul (Sapir at al. 2003: 172); this description remains valid and is often cited by experts (Cipriani 2007:1; Buti and Nava 2008: 1; Núñez Ferrer 2016: 1). Despite the conviction that profound budgetary reform is required, most authors say that the prospects for such a reform are weak. The EU budget is seen as a 'reform-immune' and 'pathdependant' system (Cipriani 2007; Heinemann at al. 2010; Benedetto, Milo 2012). Among the obstacles to profound change is one that recurs in conclusions, namely an excessive focus by the Member States on their net financial balance, exacerbated by unanimity voting in the Council on the MFF. ${ }^{\mathrm{I}}$

Any changes to the budgetary system of the EU take place slowly, but there are only a few opportunities for taking decisions on change and they are usually limited by the requirement of a unanimous vote in the Council. Certainly, the most important opportunity is during the process of deciding on the MFF. Another opportunity for stock-taking and for presenting ideas for reforms is the mid-term review of the MFF. This exercise has been gaining importance since the introduction of seven-year financial planning in the EU. Multi-year financial planning in the public sector has definite advantages, but it is not easy to create a system with the right balance between stability, predictability and flexibility, allowing quick responses to unexpected circumstances. Experience in recent years shows that the longer the time-frame, and the more dynamic the political and economic circumstances facing the EU, the greater the need for various mechanisms for interim evaluation and adjustment of the MFF (Allen, Tommasi 2001; Spackman 2002).

This paper sets out to provide insight into the upcoming mid-term review of the EU's MFF 2014-2020. It contains an overview of the evolution of the idea, the legal framework and scope and a round-up of the main issues at stake at the outset of the debate, i.e. still before the official presentation of the review by the European Commission. 


\section{What have we learnt from the past?}

The multiannual approach to spending was introduced by the European Communities in 1988, with the aim of improving budgetary discipline, making expenditure more predictable, and ensuring a steady source of financing for Community policies. ${ }^{\text {II }}$ The first financial perspective covered a period of five years (1988-1992), but all others since then have covered seven years. ${ }^{\text {III }}$ For as long as the EU has had multiannual financial plans, they have come under pressure from political and economic developments, both anticipated and unanticipated, requiring certain adjustments to agreed figures and rules. Thus, the dilemma of how to ensure stable and predictable financing for European policies while at the same time being able to respond to unexpected needs, is not new. One of the solutions to this dilemma is to schedule a review of certain elements of the plan, more or less at the midway point of its duration. This exercise has, to varying degrees, also been provided for in past EU multiannual financial perspectives and frameworks (Table 1).

Table 1: Development of the idea of a mid-term review of the EU's multiannual financial perspectives/frameworks 1988-2020

1988-1992 1993-1999

\section{0-2006} 2007-2013

\section{4-2020}

No formal midterm review or revision provided Provisions of the IIA* to be 'confirmed or for by the rules. amended' at the time of the intergovernmental conference scheduled for 1996.

Mid-term review of the agricultural guidelines intended for 1996.

\begin{tabular}{l|l|l}
$\begin{array}{l}\text { Special } \\
\text { adjustment of the } \\
\begin{array}{l}\text { Financial } \\
\text { Perspective to } \\
\text { cater for } \\
\text { enlargement in } \\
\text { 2003. }\end{array}\end{array}$ & $\begin{array}{l}\text { 'A full, wide- } \\
\text { ranging' mid-term } \\
\text { review of the MFF } \\
\text { laid down in the } \\
\text { European Council } \\
\text { Conclusions. }\end{array}$ & $\begin{array}{l}\text { Mid-term } \\
\text { review/revision of } \\
\text { the MFF laid } \\
\text { down in Article 2 } \\
\text { of the MFF } \\
\text { Regulation. }\end{array}$ \\
&
\end{tabular}

*IIA - Interinstitutional Agreement

Source: Sapala 2016

The first Financial Perspective, for 1988-1992, covered a period of five years, with no mid-term review. ${ }^{\text {IV }}$ The provisions of the second perspective covered a period of seven years (1993-1999), and although they did not explicitly provide for a comprehensive midterm review, the intergovernmental conference scheduled for 1996 (in the middle of this period) was intended as an opportunity to introduce amendments to the Interinstitutional 
Agreement (IIA) laying down the provisions of the Financial Perspective. ${ }^{\mathrm{V}}$ In addition, the European Council conclusions of 1992 provided for an interim review of the operation of the Own Resources System, and of the scope of the agricultural guidelines. ${ }^{\text {VI }}$ This could be seen as an intention to conduct a mid-term review of the Financial Perspective (Sapala 2016).

The provisions of the 2000-2006 Financial Perspective did not provide for a mid-term review or revision, aside from a special adjustment to cater for the EU's enlargement in 2004. As a consequence, the amounts were revised in the middle of the period covered, through the financial package for EU enlargement in $2003 .^{\text {VII }}$

In line with the provisions of the IIA, the Commission launched a debate on the next financial perspective by presenting a Communication in February 2004. ${ }^{\text {VIII }}$ This was around the same time as the European Parliament (EP) elections in June 2004, and the organisation of a new Commission. In September, a newly elected EP set up a special temporary committee tasked with defining its priorities and drawing up proposals for the 2007-2013 MFF. In this early debate, the EP's position focused on appropriate financial resources to match the EU's political ambitions and growing responsibilities, modernising the structure of the EU's budget, and improving the quality of its implementation. A midterm review of the MFF was not among the most hotly debated issues, but as a result of the negotiations on the 2007-2013 MFF it was included for the first time in both the Council conclusions and the IIA. The Council asked the Commission 'to undertake a full, wide-ranging review covering all aspects of EU spending, including the CAP, and of resources, including the UK rebate' (Council of the EU 2005). This agreement was further developed in Declarations 1 and 3 attached to the IIA, which specified that the results of the review were to be accompanied by an assessment of the functioning of the IIA and, if necessary, by proposals for improving it. Moreover, the EP was to be involved in the review at all stages of the procedure, including the formal follow-up steps. ${ }^{\text {IX }}$ Some say that the idea was the result of a compromise between those Member States that expected a more thoroughgoing reform of the CAP on the one hand, and those in favour of abolishing the UK rebate on the other (Taylor 2011).

The results of the review were meant to be presented by the Commission in 2008/2009. In December 2009 the European Council encouraged the Commission to present the review covering all aspects of spending and resources (European Council 2009), 
but important circumstances and events delayed the debate until late 2010. The European elections in 2009 and the formation of a new Commission (Barroso II), as well as the protracted ratification of the Lisbon Treaty (which was only completed in December 2009) stood in the way of the presentation of the review. Moreover, the economic crisis had just struck the Member States. None of these pressures were conducive to a radical debate about the budget (Begg 2010).

Nevertheless, in order to gather ideas on reforming the budget in preparation for the review, the Commission carried out public consultations (from September 2007 to June 2008), which generated a substantial response from academic and expert circles, governments, and NGOs. Many participants in the debate saw the review as an opportunity for change and had high expectations (European Commission 2008). The EP expressed its ambitious position on the budget review in a resolution in March 2009, with a view to feeding into the Commission's proposal (European Parliament 2009).

When the Commission finally presented the results of its budget review on 19 October 2010, both the EP and experts were disappointed by the lack of any proposals for genuine reform (Begg 2010, Becker 2012). They assessed the Commission's document as rather weak and lacking any sense of a clear break with the past. It would not, therefore, have any impact (Begg 2010). By the time the review was published, the 2007-2013 MFF had already been revised four times; for example, to cover the additional needs of the Galileo project and the Food Facility. ${ }^{\mathrm{X}}$

The Lisbon Treaty created the legal basis for the MFF - in place of the voluntary IIA used previously - mandating the form of a regulation and establishing a new role for the EP. Moreover, the Europe 2020 Strategy presented at the beginning of 2010 prompted calls for a new MFF, rather than a revision of the current one. In order to take all these factors into account, the EP decided to focus on the next MFF, and set up a special committee for debate on the EU's finances post-2014. ${ }^{\mathrm{XI}}$ Thus, what was meant to be the first formal, full and wide-ranging mid-term review of the MFF, turned out to be merely a contribution to the debate on a future MFF (Sapala 2016). 


\section{The scope of the mid-term review of the MFF 2014-2020 as laid down in the legislation}

Given the unsatisfying experience with the mid-term review of the 2007-2013 MFF, it was feared that a similarly empty promise might be made under the pressure of the negotiations on 2014-2020. From the beginning of the debate, therefore, the EP strongly insisted that, if the MFF period were made longer than five years, 'an obligatory mid-term review allowing for a quantitative as well as qualitative analysis and stock-taking on the functioning of the MFF' would be necessary (European Parliament 2011). Another argument in favour of the review stemmed from a conviction that a newly elected Parliament and newly installed European Commission have the right to reassess the EU's political priorities. Moreover, the EP called for a 'specific procedure, including a binding calendar, which ensures the full involvement of the Parliament' (ibid) and provides real scope to revise the MFF ceilings, should the review establish that they are inadequate. This became one of the most important demands and conditions for the EP's consent to the 2014-2020 MFF.

The Commission's legislative proposal for the MFF regulation included a point referring to a mid-term assessment of the implementation of the MFF. It was developed during the negotiations and, eventually, a compulsory mid-term review plus an optional revision (called the mid-term review/revision) were introduced into the Council Regulation laying down the MFF for the 2014-2020 (known as the MFF Regulation). ${ }^{\mathrm{XI}}$ The formalisation of this dual exercise, was undeniably a success for the EP, although the demand for a special procedure with a binding calendar was not included in the provisions. This detail may therefore be put on the list of issues for the negotiations of the post-2020 MFF.

It should be emphasised that according to Article 2 of the MFF Regulation the review should, as appropriate, be followed by a proposal for a revision. Therefore, whether a relevant procedure for the revision will be triggered, depends on the European Commission. In this case it would be the special legislative procedure laid down in Article 312 TFEU. It requires a unanimous vote in the Council, unless the European Council authorises the Council to act by qualified majority, and the consent from the EP given by a majority of its members. 
According to the MFF Regulation, the Commission should present the mid-term review/revision by the end of 2016 at the latest. It should take into account the updated economic situation and macroeconomic projections. Since there is no synchronisation between the duration of the MFF and the Commission's or EP's legislative terms, such a review/revision should allow the newly elected EU institutions to reassess the EU's political priorities and endow the MFF with renewed democratic legitimacy. For this reason, the procedure is sometimes, especially in the EP, referred to as 'the post-electoral' review/revision.

Moreover, based on the Commission's political declaration attached to the MFF regulation it can be expected that particular attention will be paid to the functioning of the global margin for payments in order to ensure that the overall payments ceiling remains available throughout the period.

However, if any changes to the regulation are introduced these should not result in a reduction of the national envelopes. ${ }^{\mathrm{XIII}}$ In addition, the mid-term review/revision will be an opportunity to consider the appropriate duration of the next MFF, with a view to aligning it with the political cycles of the EU institutions.

\section{What issues are at stake and why?}

There are reasons to expect a thorough mid-term review of the MFF 2014-2020 with thoughtful conclusions which can be followed by a proposal for a revision of the regulation. The list of issues at stake includes both current problems requiring immediate action, and long-standing, contentious aspects of the MFF. The former concern the MFF's flexibility, and adjustment of expenditure ceilings in the light of various recent crises and new political priorities. The latter would cover aspects that need to be considered with a view to a post-2020 MFF.

Implementation of the 2014-2020 MFF has already proven to be challenging in its first two years. First of all, the resources agreed for the current MFF were not only substantially lower than the Commission's proposal, but also below those of the 2007-2013 period. Secondly, the reduced MFF had to absorb the abnormal backlog of payments (€24.7 billion in 2014) that had built up in the EU budget since 2011 (D'Alfonso, Sapala 2015). Thirdly, since December 2013, when the current MFF was adopted, the political situation in the EU 
has changed significantly, and the need for funding has dramatically increased in some areas. Some of the decisions and actions taken by the EU in response to unexpected domestic and international developments, such as the refugee crisis, the conflict in Ukraine, the increased threat of terrorism, agricultural sector crises and the protracted economic crisis in Greece, have major budgetary consequences. The greatest pressure for increased spending has been on MFF heading 3, 'Security and citizenship', and heading 4, 'Global Europe', and resources under these headings have been completely exhausted. Moreover, in order to mitigate the impact of the ongoing economic downturn, a decision was taken to establish a new financial initiative with a contribution from the EU budget: the European Fund for Strategic Investments (EFSI). This decision entailed shifts and cuts to amounts previously allocated to Horizon 2020 and the Connecting Europe Facility.

Therefore, although barely two years have passed since the beginning of the current MFF, in order to accommodate these needs and ensure the smooth implementation of the EU budget, the budgetary authority (the Council and the EP) has already had to resort to almost all the special, 'last-resort' margins and flexibility instruments provided for in the MFF Regulation (Table 2).

Table 2. Flexibility provisions and special instruments employed so far in the 2014-2020 MFF $\mathrm{XIV}$

\begin{tabular}{|c|c|c|c|c|}
\hline Instrument & Amount & Decision & $\begin{array}{l}\text { Legal basis in the } \\
\text { MFF regulation }\end{array}$ & Purpose \\
\hline Contingency Margin & $€ 3.2$ billion & $\begin{array}{l}\text { Decision (EU) } \\
\text { 2015/435 of } 17 \\
\text { December } 2014\end{array}$ & Article 13 & $\begin{array}{l}\text { To reduce the } \\
\text { backlog in payments } \\
\text { in } 2014 \text {. } \\
\text { The margin was used } \\
\text { at no additional cost } \\
\text { to national budgets } \\
\text { (due to unexpected } \\
\text { additional revenue } \\
\text { for the year 2014), } \\
\text { but it will have to be } \\
\text { offset against } \\
\text { margins under the } \\
\text { payment ceilings for } \\
2018,2019 \text { and } 2020 \text {. }\end{array}$ \\
\hline $\begin{array}{l}\text { Flexibility } \\
\text { Instrument }\end{array}$ & $€ 1.53$ billion & $\begin{array}{l}\text { Decision (EU) } \\
\text { 2015/2248 of } 21 \\
\text { October } 2015\end{array}$ & Article 11 & $\begin{array}{l}\text { To finance support } \\
\text { for measures for } \\
\text { managing the refugee } \\
\text { crisis }\end{array}$ \\
\hline $\begin{array}{l}\text { Global Margin for } \\
\text { Commitments }\end{array}$ & $€ 543$ million & $\begin{array}{l}\text { Amending Letter No } \\
1 \text { to the Draft } \\
\text { General Budget } \\
2016\end{array}$ & Article 14 & $\begin{array}{l}\text { To finance the } \\
\text { European Fund for } \\
\text { Strategic Investments }\end{array}$ \\
\hline Emergency Aid & $€ 98.1$ million in & Union's general & Article 9 & To tackle migration \\
\hline
\end{tabular}




\begin{tabular}{|c|c|c|c|c|}
\hline Reserve & $\begin{array}{l}\text { 2014, €282.5 million } \\
\text { in } 2015 \text { and } € 150 \\
\text { million in } 2016\end{array}$ & $\begin{array}{l}\text { budgets for the } \\
\text { financial year } 2014 \text {. } \\
2015 \text { and } 2016\end{array}$ & & crisis \\
\hline $\begin{array}{l}\text { Revision in case of } \\
\text { late adoption of } \\
\text { rules of } \\
\text { programmes under } \\
\text { shared management }\end{array}$ & $€ 21.1$ billion & $\begin{array}{l}\text { Council Regulation } \\
\text { (EU, Euratom) } \\
2015 / 623 \text { of } 20 \\
\text { April } 2015\end{array}$ & Article 19 & $\begin{array}{l}\text { Transfer of unused } \\
\text { allocations for 2014, } \\
\text { due to a late } \\
\text { agreement on the } \\
\text { MFF and a delayed } \\
\text { start to } \\
\text { implementation }\end{array}$ \\
\hline
\end{tabular}

Table compiled by the author

In addition to the flexibility instruments applied so far, on the basis of Article 15 of the MFF and the European Council Conclusions of 27/28 June 2013 it was decided to frontload the appropriations for programmes supporting youth employment, research and small and medium-sized enterprises, which consequently reduced the level of appropriations for subsequent years. Similarly, in order to boost uptake of the European Structural and Investment Funds in Greece, it was decided that the level of initial prefinancing paid in 2015 and 2016 would be increased (Regulation (EU) 2015/1839). These decisions put an additional pressure on the budget.

It should be noted that most of the adjustments made to the MFF so far do not increase overall MFF ceilings; they merely shift amounts already allocated and will have to be offset in full against margins in the years 2018-2020. This raises questions about the consequences of these measures for the functioning of the MFF through to 2020. The picture may become even more complicated in coming years since some problems, especially the refugee crisis, are likely to continue and require further political action and, hence, financial support. Such intensive recourse to flexibility provisions so soon after the start of the new MFF provides arguments for advocates of a greater flexibility and of a revision, including an increase in the ceilings of the MFF.

Alongside an assessment of the functioning of the 2014-2020 MFF, the debate around the review/revision will be an opportunity to highlight certain issues related to the EU's finances beyond the current MFF. The most fundamental question concerns reforming the financing of the EU budget. The publication of the MFF review is likely to coincide with presentation of the report by the High-Level Group on Own Resources led by Mario Monti and could feed into the content of the Commission's document. A bold reform of the revenue side of the EU budget is as much awaited as difficult to introduce, but it could remedy many problems on the expenditure side. 
Another issue present in the current budgetary discussions, especially in the EP, is the unity of the budget. Recently developed trust funds used to finance certain EU measures raise questions about the character and democratic accountability of these new tools. Similar concerns are expressed about the proposals to create a fiscal and budgetary capacity of the euro area. ${ }^{\mathrm{XV}}$ If further developed, these ideas may have a big impact on the architecture of the EU budget after 2020.

Given the experience of the current MFF and the frequent use of the various flexibility tools, it can be expected that new ideas to improve this aspect will feature in the debate. Furthermore, growing economic and political instability requires rapid reactions; thus, we should expect rather more than less flexibility in the EU budget. The issue, however, raises many new questions, for example about types of flexibility, their limits, and consequences for the configuration of budgetary priorities (Mijs, Schout 2015; Núñez Ferrer 2016).

Changes in the decision-making and negotiation process of the MFF could be one of the remedies for the drawbacks of the budgetary system of the EU. The current procedure is criticised for many reasons, not least because it emphasises a juste retour ('fair return') approach by the Member States. Suggestions that have already been made for reform include a shift in decision making power on the structure of expenditures from the European Council to the EP, and modification of decision making by application of qualified majority voting instead of unanimity in the Council (Kölling 2014; Fuest at al 2015).

Furthermore, as indicated in the recital 3 of the MFF Regulation, the mid-term review/revision should be an opportunity to renew the debate about aligning the duration of the MFF with the legislative terms of the main institutions. This, seemingly technical aspect, may have important consequences for institutional and budgetary responsibilities as well as the implementation of EU programmes and policies. The decision on the duration of the MFF will have to be taken before the presentation of a proposal for the post-2020 MFF, i.e. before January 2018.

Both the review of the current MFF and the proposal for the post-2020 MFF will also be opportunities to promote the Commission's broader "Budget Focused on Results" initiative. ${ }^{\mathrm{XVI}}$ Performance based budgeting is becoming a leading concept for the overall construction of the EU budget; and it triggers changes in the way the funds are allocated and the results are measured. 


\section{The positions of the main decision-makers}

The review of the MFF is included in the Commission's 2016 Work Plan under 'New initiatives', but the exact timing of the presentation of documents has not yet been announced. The issue is, however, high on the Commission's agenda and, according to President Juncker, the review should be used as an opportunity to "orient the EU budget further towards jobs, growth and competitiveness". Kristalina Georgieva, Commission Vice-President for the Budget, has on many occasions also expressed her commitment to a thorough review, taking a close look at the budgets' priorities and the options for improving the way it functions. ${ }^{\mathrm{XVII}}$

The Council has not yet presented its position, and it is not expected to do so before the Commission announces the results of the next review and any proposal for a revision of the MFF. The Council did, however, initiate an informal debate on the future MFF at a Dutch Presidency conference on this topic organised in January 2016 in Amsterdam. Moreover, the ministers of finance discussed the matter over an informal meeting on 22 April 2016. It should be emphasised that the Council plays a central role in the special procedure leading to a revision of the $\mathrm{MFF}$, and that any changes to the Regulation require a unanimous vote by the Member States. It is fair to assume, therefore, that the Council's position will be crucial for the outcome of the upcoming review/revision.

The EP has consistently and firmly supported the idea of an obligatory, genuine, postelectoral mid-term MFF review and, if necessary, a revision of the MFF regulation. Now that the time has come to put the provisions of the review/revision into effect, the EP's ambition is to set the agenda and to be at the forefront of the debate. Therefore, in December 2015, the Committee on Budgets (BUDG) launched discussions with a view to adopting a strategic own-initiative report ahead of the Commission's review and proposal for a revision. On 6 July 2016 the EP adopted the resolution on the topic. It concluded that the implementation of the 2014-2020 MFF has proved exceptionally difficult, the ceilings have proved to be too tight in some headings and the MFF has 'essentially been pushed to its limits'. Therefore, the EP considers the revision of the MFF, including the figures, as 'absolutely indispensable' (European Parliament 2016).

In parallel to this, the EP set out a list of changes to be considered for the second half 
of this MFF period: significant reinforcements to funds and initiatives in the area of migration and the refugee crisis, and the EU's external actions; offsetting of the EFSIrelated cuts to Horizon 2020 and the Connecting Europe Facility; the continuation of the Youth Employment Initiative; and transfer to the following year's budget of any surplus resulting from under-implementation of programmes, fines or de-commitments. Furthermore, the Parliament's document incudes considerations concerning the post-2020 MFF. In particular, the EP proposes that the future MFF would be better aligned with the political cycle of the EU institutions and last $5+5$ years for programmes requiring longterm programming (with compulsory mid-term revision) and 5 years for other elements of the MFF. The EP calls for a thorough reform of own resources, for enhanced flexibility of the MFF and proposes to set up a permanent crisis reserve counted over and above the MFF ceilings. Furthermore, the Parliament sees a shift towards qualified majority voting in the Council as a way to improve the procedure for the adoption of MFF regulations.

As far as other stakeholders are concerned, the most visible in the debate have been local and regional authorities and their associations, such as Eurocities or the Conference of Peripheral Maritime Regions of Europe. The latter presented a technical paper containing preliminary deliberations on the review/revision, emphasising its importance for the regions (Conference of Peripheral Maritime Regions of Europe 2016). Moreover, in June 2016 the Committee of the Regions adopted an opinion on the issue, which largely converges with the Parliament's views and demands (Committee of the Regions 2016).

The ambitious proposals and demands put forward by the EP have already boosted the debate, but the formal start of the procedure will depend on when the Commission presents the MFF review and any proposal for revision. This has not yet been announced, and it is worth noting that the later the presentation of the review/revision takes place, the more it may overlap or conflict with other events provided for in legislation, such as the mid-term review of sectoral policies (2017) and the presentation of a draft post-2020 MFF (before 1 January 2018). Finally, it is not clear to what extent the United Kingdom's decision to leave the EU will have an impact on the course and direction of the debate. ${ }^{\mathrm{XIII}}$ 


\section{Conclusions}

Given the magnitude of the new challenges confronting Europe and the scope of the review/revision as intended by Article 2 of the MFF regulation, the European Commission is expected to propose concrete changes. The list of problems to be addressed is extensive. They concern both the difficulties implementing the current MFF and long-awaited reforms to EU financing.

As demonstrated in this paper, short and medium-term changes to the EU budgetary system are expected by the EP, academic and expert circles, and stakeholders. The first opinions and official position papers were recently presented by the Member States or their representatives. They include proposals for both minor adjustments and far-reaching changes. ${ }^{\text {IIX }}$ Experience shows, however, that amendments and adjustments to the MFF are never easy. Often the problem lies not in the lack of proposals for change, but in securing the unanimity needed to adopt them.

\footnotetext{
* The views presented in this article are solely those of the Author and should not be attributed to the European Parliament, the European Parliamentary Research Service or any other institution, agency or body of the European Union.

I As the matter of fact, the recent study by Richard Crowe shows that participation by the Member States represented in the European Council in the decision-making procedure leading to the agreement on the MFF, is more extensive in practice than what is provided for in the treaty (Crowe 2016).

II The first three financial periods, 1988-1992 and 1993-1999 and 2000-2006, were known as 'financial perspectives'. The provisions for 2007-2013 introduced the term 'multiannual financial framework', also used for 2014-2020.

III Under Article 312 of the Treaty on the Functioning of the EU, the MFF must cover a period of at least five years.

IV Interinstitutional Agreement on Budgetary Discipline and Improvement of the Budgetary Procedure, 15.07.1988, L 185/33 (Delors I package).

V Article 24 of the Interinstitutional Agreement of 29 October 1993 on budgetary discipline and improvement of the budgetary procedure 93/C 331/01 (Delors II package).

VI See: Council Conclusions, Part C Future financing of the Community, Delors II Package, Edinburgh, 12 December 1992.

VII The revision based on Article 25 of the Interinstitutional Agreement of 6 May 1999 between the European Parliament, the Council and the Commission on budgetary discipline and improvement of the budgetary procedure.

VIII Communication from the Commission COM(2004)101, 26 February 2004; Before this, in February 2003 the Commission adopted an internal communication on the preparation of a new perspective (SEC(2003)241/2). It then updated the vision in July 2004 in Communication COM(2004) 487, 14 July 2004. Parliament expressed its position in a resolution in April 2004 on building our future: policy challenges and budgetary means of the enlarged Union 2007-2013.

IX Interinstitutional Agreement between the European Parliament, the Council and the Commission on budgetary discipline and sound financial management, 2006/C 139/01.

$\mathrm{x}$ The Galileo programme is the EU initiative launched in 1999. It is aimed at creating a state-of-the-art global
} 
satellite navigation system, providing a highly accurate global positioning service under civilian control. The Food Facility was set up in 2008 in order to provide a rapid EU response to soaring food prices in developing countries.

XI Special Committee on Policy Challenges and Budgetary Resources for a Sustainable European Union after 2013 (SURE).

XII Article 2 and recitals 2, 3, 9, 11 refer to the mid-term review/revision of the MFF. This procedure should not be confused with the flexibility provisions and instruments that allow for correcting and revising the MFF during its duration, which are specified in Articles 17-22 of the MFF regulation. Council Regulation (EU, EURATOM) 1311/2013 laying down the multiannual financial framework for the 2014-2020, OJ L 347.

XIII Amounts pre-allocated to each Member State in the areas of rural development, fisheries and cohesion policy.

XIV The table does not include funds mobilised under the European Globalisation Adjustment Fund (€81 million in 2014 and $€ 44.2$ million in 2015), and the EU Solidarity Fund (€126.7 million in 2014 and $€ 50$ million in 2014) as they are more frequently applied instruments to tackle specific problems.

$\mathrm{XV}$ They were expressed for example in the European Parliament during the debate on the own initiative Report on budgetary capacity for the Eurozone (2015/2344(INI)).

XVI For more about the initiative see: European Commission, Roadmap, http://ec.europa.eu/smartregulation/roadmaps/docs/2016 sg_003 mff 2014-2020 en.pdf, [accessed on 20.04.2016]; European Commission, Budget Focused on Results, http://ec.europa.eu/budget/budget4results/index en.cfm [accessed on 15.02.2016].

XVII For example during the conference "EU budget focused on results" on 22 October 2015 in Brussels, http://ec.europa.eu/budget/budget4results/programme/index en.cfm [accessed on 15.02.2016].

XVIII The Commissioner in charge of Budget Kristalina Georgieva clarified that by the end of 2016, when the Commission is supposed to present the review, the UK objectives will not be known and they cannot be taken into account in the document. See: Read-out of the College meeting of 27.07.2016, Audiovisual Services of the European Commission.

XIX See for example: 'Position paper Nederland - Tussentijdse evaluatie MFK', Den Haag, Nederland, juli 2016, www.rijksoverheid.nl [accessed on 29.07.2016] and Schäuble Wolfgang, 2016, 'The future of EU finances', speech presented during a symposium on 'The Future of EU Finances' in Brussels, 15 January 2016.

\section{References}

- Allen Richard and Tommasi Daniel (eds), 2001, Managing public expenditure. A reference book for transition countries, OECD, Paris.

- Begg Ian, 2010, 'Mollifying everyone, pleasing no-one? An assessment of the EU Budget Review' in European Policy Analysis, November.

- Benedetto Giacomo, 2015, 'How rising Euroscepticism could affect future EU budget revenue negotiations', EUROPP, LSE blog, http://blogs.lse.ac.uk/europpblog/2015/12/08/how-will-risingeuroscepticism-impact-eu-budget-negotiations [accessed on 17 December 2015].

- Benedetto Giacomo and Milio Simona (eds), 2012, European Union Budget Reform. Institutions, Policy and Economic Crisis, Palgrave Macmillan, Basingstoke.

- Buti Marco and Nava Mario, 2008, “Constrained Flexibility” as a Tool to Facilitate Reform of the EU Budget' in Economic Papers 326, Directorate-General for Economic and Financial Affairs, European Commission.

- $\quad$ Cipriani Gabriele, 2007, Rethinking the EU Budget. Three Unavoidable Reforms, Centre for European Policy Studies, Brussels.

- Committee of the Regions, 2016, 'Opinion on the mid -term Revision of the Multiannual Financial Framework’, 118 Plenary Session, 15-16 June 2016, COTER-VI/014.

- Conference of Peripheral Maritime Regions of Europe, 2016, 'Technical Paper from the CPMR General Secretariat. The mid-term review of the EU budget: issues at stake for CPMR regions'.

- Council of the European Union, 2005, Financial Perspective 2007-2013, Note 15915/05. 
- Council Regulation (EU) 1311/2013 laying down the multiannual financial framework for the 20142020, OJ L 347.

- Crowe Richard, 2016, 'The European Council and the Multiannual Financial Framework', Cambridge Yearbook of European Legal Studies, Available on CJO 2016 doi: 10.1017/cel.2016.2.

- D'Alfonso Alessandro and Sapala Magdalena, 2015, 'Payments backlog in recent EU budgets. Lessons learnt and outlook', EPRS, European Parliament.

- $\quad$ European Commission, 2008, Communication 'Reforming the budget, changing Europe - A public consultation paper in view of the 2008/2009 budget review', SEC/2007/1188 final.

- $\quad$ European Council, 2009, Conclusions 10/11 December 2009, EUCO 6/09.

- $\quad$ European Parliament, 2009, 'Resolution of 25 March 2009 on the Mid-term Review of the 2007-2013 Financial Framework’ (2008/2055(INI)).

- $\quad$ European Parliament, 2011, 'Resolution of 8 June 2011 on Investing in the future: a new Multiannual Financial Framework (MFF) for a competitive, sustainable and inclusive Europe’ (2010/2211(INI)).

- European Parliament, 2016, 'Resolution of 6 July 2016 on the preparation of the post-electoral revision of the MFF 2014-2020: Parliament's input ahead of the Commission's proposal' (2015/2353(INI)).

- Fuest Clemens, Heinemann Friedrich and Ungerer Martin, 2015, 'Reforming the Financing of the European Union: A Proposal', Intereconomics 50: 288.

- Heinemann Friedrich, Mohl Philipp and Osterloh Stephen, 'Reforming the EU Budget: Reconciling Needs with Political-Economic Constraints9, European Integration, XXXII(1): 59-76.

- Kölling Mario, 2014, 'Reform options for the EU budget - First reflections on the new departure for a new EU budget', Perspectives on Federalism, VI(3): 218-237.

- $\quad$ Mijs Arnout, Schout Adiaan, 2015, Flexibility in the EU Budget. Are there limits?, Clingendael, Den Haag.

- Núñez Ferrer, Jorge, 2016, Briefing paper for the Presidency Conference on the Multiannual Financial Framework, Netherlands Ministry of Foreign Affairs and Ministry of Finance, 28 January 2016.

- Sapala Magdalena, 2016, 'Mid-term review/revision of the MFF. Key issues at the outset of the debate', Briefing, EPRS, European Parliament.

- Sapir André, Aghion Philippe, Bertola Giuseppe, Hellwig Martin, Pisani-Ferry Jean, Rosati Dariusz and Viñals José, 2003, An Agenda for a Growing Europe. Making the EU Economic System Deliver, Report of an Independent High-Level Study Group established on the initiative of the President of the European Commission.

- $\quad$ Spackman Michael, 2002, Multi-year perspective in budgeting and public investment planning, OECD, Paris.

- Taylor Simon, 2011, 'Be bold on budget reform', European Voice, 18 September 2011. 